\title{
RECONSTRUCTION OF THE 2007 JAKARTA FLOOD BY J2000 HYDROLOGICAL MODEL
}

\author{
Miga Magenika Julian ${ }^{1,2}$ \\ ${ }^{1}$ Department for Geoinformatics, Hydrology and Modelling, Friedrich Schiller University of Jena, Jena, Germany \\ ${ }^{2}$ Faculty of Earth Sciences and Technology, Institute of Technology, Bandung, Indonesia
}

\section{SHORT PAPER}

\section{INTRODUCTION}

Climate is changing globally, has changed in the past, and will change in the future (IPCC, 2001). The issues of climate changes are also noticed in the Jakarta, Indonesia. In Jakarta, climate changes are indicated by the increase of air temperature by $1.2^{\circ} \mathrm{C}$ in the $20^{\text {th }}$ century (Julian et al., 2011), more intense rainfall, long-term drought (Oki et al., 2013), and sea level rise at a rate of 1-8mm/year (Förster et al., 2011). As a center of government, trade, development, investment and education brands Jakarta and surrounding areas as a promising area in Indonesia. This triggers to urbanization that results in the alteration of forest cover to agriculture and residential area (Amien et al., 1996; Verburg et al., 1999; Firman, 2009). Consecutive alterations of forest cover to agriculture and residential area lead to the waterproofing of soil. This affects a decrease in infiltration rate. Conversions of forest cover in the watersheds also lead to an increase of erosion rate in the upper and middle river basin. It causes sedimentation in the river networks of the low land area (i.e. Jakarta) and reduces drainage capacity. Coupling effects of climate and land-use changes causing Jakarta are vulnerable to flooding. The flood in Jakarta in February 2007 is the worst flood during a century (Texier, P., 2008). Almost 60\% of Jakarta areas were affected by flooding, 80 people died and reached 8.6 trillion Indonesian Rupiah (IDR) ( 700 million US\$) losses (Hasanah, et al., 2013).

In order to assimilate issues associated with the changes of climate and land use on hydrological processes, an appropriate tool must be employed. This tool must able to handle factor relates to the transport of water. Here, the distributed, process-oriented hydrological model named J2000 (Krause, 2001) was performed to simulate the hydrological dynamics in the study area. The J2000 hydrological model has been implemented in the upper part of Citarum basin (Julian et al., 2013), and the model performed well with the efficiency of 0.76 Nash-Sutcliffe and $0.14 \%$ deviation.

In this paper, hydrological dynamics in Ciliwung basin will be reconstructed during the 2007 Jakarta flood, at a daily time step. Reconstruction will cover one year before and after the 2007 Jakarta flood. Katulampa sub-basin in the upper Ciliwung basin will be used as a study area. The hydrological dynamics in Katulampa sub-basin must be understood. The Katulampa gauging station has an important function as an early warning system of water flow information before entering the Jakarta area.

Figure 1 shows the Katulampa sub-basin. Several precipitations and climate stations are used as input of hydrological modelling. The climate stations comprise temperature, humidity, wind speed, and sunshine duration parameters. Observed runoff at the Katulampa gauging stations is used for validating the model results. In term of physical geography, the total area of Katulampa sub-basin is $151 \mathrm{~km}^{2}$. The elevations are ranging from $343 \mathrm{~m}$ to $2975 \mathrm{~m}$ with $1000 \mathrm{~m}$ average. The slope varies $0.1^{\circ}$ to $43^{\circ}$ with $12^{\circ}$ average. Landuse in Katulampa is dominated by agricultural with $49 \%$ of total area. The geological condition is formed by volcanic activities from Salak Mountain and Gede-Pangrango Mountain. Latosol and andosol are the major soil type in this area. The average annual rainfall is $3392 \mathrm{~mm}$. During wet season from November to April, rainfall is measured $405 \mathrm{~mm} / \mathrm{month}$ whilst $160 \mathrm{~mm} /$ month in the dry season from May to October. The average temperature is ranging from $25^{\circ} \mathrm{C}$ to $32^{\circ} \mathrm{C}$. 


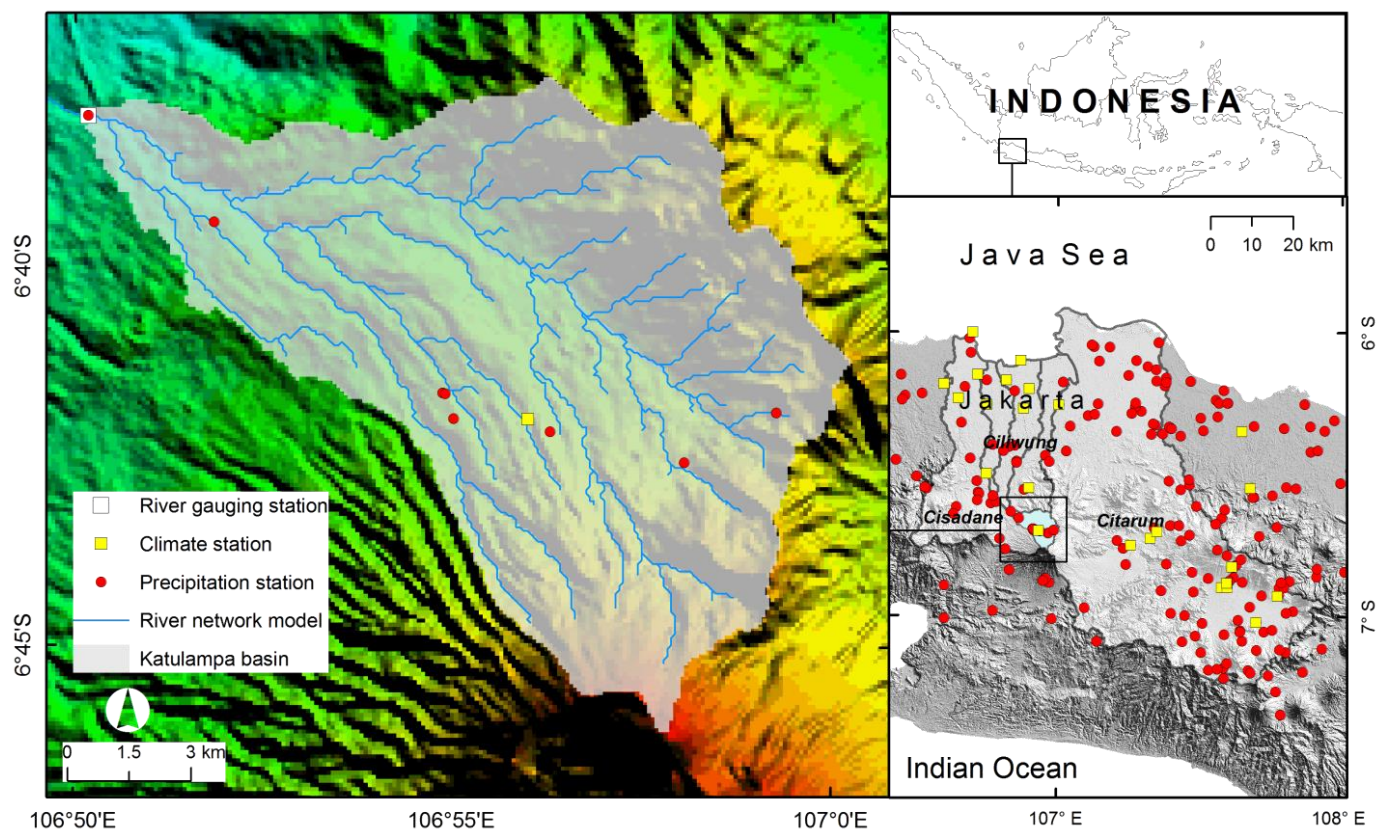

Figure 1- Study area: Katulampa in the upper part Ciliwung basin

\section{SPATIAL HYDROLOGICAL MODELLING}

The J2000 hydrological model (Krause, 2001) was implemented in this study. The J2000 is a distributed, processoriented hydrological model for hydrological processes simulation in meso- and macro-scale basin (Krause, 2001). It is executed in the Jena Adaptable Modelling System (JAMS) (Kralisch and Krause 2006, Kralisch et al. 2007), which is a software framework for component-based development and application of environmental models. The J2000 comprises modules to represent the hydrological physical processes. Each module contains a number of module parameters which have to be adapted during the application. The main inputs of the model are hydrometeorology data (precipitation, air temperature, humidity, wind speed, sunshine duration), a topographic data in Digital Elevation Model (DEM), land use distribution, soil information and geological condition. A representative of the spatial distribution of topographic details, land use, soil, and geology is generated by Hydrological Response Units (HRUs). HRUs are distributed, heterogeneously structured entities with common climate, land use, and underlying pedo-topo-geological associations controlling their hydrological dynamics (Flügel, 1995). HRUs are utilized as model entities for J2000.

The J2000 describes the process-oriented hydrological cycle of a drainage basin as a set of modules and model parameters. Each module can be employed independently depending on the objectives and the availability of data. The $\mathrm{J} 2000$ produces four different runoff components: overland or surface runoff $(R D 1)$, fast interflow $(R D 2)$, slow interflow $(R G 1)$, and baseflow $(R G 2)$.

At the beginning, the precipitation is divided into rain and snow depends on the air temperature. The assumed threshold of air temperature must be defined in order to determine the amount of rain and snow. Above the threshold, the precipitation will be defined as rain and vice versa as a snow. In this study where the air temperature is constantly above zero degrees Celsius, all amount of precipitation falls as rain.

The interception module in J2000 estimates the maximum interception storage depending on leaf area index and form of precipitation. When the maximum storage capacity is exceeded, additional precipitation is considered as throughfall which is transferred to the subsequent module. The interception storage is emptied by evaporation.

Soil water module is structured in process units (infiltration, evapotranspiration) and two specific storage units (middle pore storage $=$ MPS, large pore storage $=$ LPS, depression storage). MPS represents the pores with a diameter $0.2-50 \mu \mathrm{m}$ with a volume equivalent to usable field capacity. MPS follows water against gravity and free drainage. MPS is filled by infiltration and emptied by evapotranspiration only. LPS represents the pores with a diameter $>50 \mu \mathrm{m}$ with a volume equivalent to air capacity of the soil. Water in LPS does not hold against gravity. LPS is filled by infiltration, emptied by lateral flow (interflow) and vertical flow (percolation) processes to recharge groundwater. 
Firstly, the input of soil water is come from precipitation and snows melt (if any). Water is infiltrated and distributed between two storages (MPS and LPS). Maximum infiltration rate is calculated based on the actual soil water saturation and empirical seasonal calibration coefficients. Distribution of water between MPS and LPS is computed depending on the saturation of MPS and the remaining waters seep to LPS. Excess water which is not able to infiltrate is transferred to the depression storage. The maximum depression storage must be defined according to the elevation condition. If the maximum depression storage capacity is reached, the excess water is transported as overland or surface runoff (RD1). A reduction factor of water in MPS (RF) is made by evapotranspiration (evaporation from the soil surface and transpiration from by vegetation cover) and saturation of MPS. At the end, the maximum actual evapotranspiration (AET) is calculated as a factor of RF and potential evapotranspiration (PET). Here, PET is calculated according to Penman-Monteith (Montheith, 1975).

Water from LPS is distributed into a lateral flow (interflow) (RD2) and vertical flow (percolation) to recharge groundwater depending on the slope. Water in groundwater module is distributed into two storage units. The upper groundwater storage $(R G 1)$ represents in the weathered loose materials on top of the bedrock with high permeability and short retention time. The lower groundwater storage $(R G 2)$ represents saturated areas for a long time with low permeability and long retention time. The recharge of groundwater comes from the percolation of LPS. Emptying of groundwater is made by lateral underground runoff component and capillary rise on the saturated zone. The capillary rise is calculated if the groundwater storage is greater than the soil moisture.

Percolation from upper soil is distributed to $R G 1$ and $R G 2$ according to the slope in specific model entity and coefficient for the distribution of water into two groundwater storages. Outflow from the two storages is calculated with a linear outflow function using retention coefficient of storages and current storage volume. Latterly, the lateral routing transports water from one entity to another entity in the lower area until reaching stream network. Reach routing calculates the water transport in the river network. Flow processes in river network apply kinematic water approach and the velocity according to Manning and Strickler (Krause, 2001).

Evaluation of modelling quality is assessed using the Nash-Sutcliffe coefficient (NS) (Huang and Liang, 2006), the deviation between simulated and observed results, and the correlation coefficient $(r)$.

\section{RESULT AND ANALYSIS}

Reconstruction of hydrological dynamics in Katulampa sub-basin was carried out by using J2000 hydrological model. The period of reconstruction is covering from 1 January 2006 to 31 December 2007. In February 2007, the great flood in Jakarta has occurred. Observed runoff in upper Ciliwung basin in Katulampa gauging station was used to compare the model output and the observed ones. During the flood event in February 2007, the precipitation in Katulampa reached $122 \mathrm{~mm}$ /day whereas the daily average precipitation throughout 1990-2008 in the wet season is respectively $13.5 \mathrm{~mm} /$ day. At the same time, the observed runoff was recorded $98 \mathrm{~m}^{3} / \mathrm{s}$.

The model requires following inputs as daily meteorological parameters (precipitation, temperature, humidity, wind speed, and sunshine duration), topographic details, soil, and geological information. 90m SRTM (Shuttle RADAR Topographic Mission) was utilized to derive elevation, slope, aspect, and river network model. The 1:25000 scale of land use map in 2005, soil and geology map in a scale of 1:250000 were used.

The comparison between daily simulated and observed runoff is shown in Figure 2. The statistics are summarized in Table 1. The model performed reasonably well. It can accommodate the seasonal dynamics during the wet season (more precipitation) and dry season (less precipitation). The efficiencies resulted in Nash-Sutcliffe coefficient $(N S)$ by $0.60,-1.1 \%$ deviations, and coefficient correlation $(r)$ by 0.84 . The model can also catch the highest peak perfectly during the flood event. The first period of simulation is termed as the initializing time. During the initializing time, soil water and groundwater storages are filled up. At this period (approximately January to June 2006), the under-predicted runoffs have occurred.

Table 1. Statistic of observed runoff vs. simulated runoff in Katulampa gauging station

\begin{tabular}{c|c|c|c}
\hline (in $\left.\mathrm{m}^{3} / \mathrm{s}\right)$ & Minimum & Maximum & Average \\
\hline Simulated runoff & 0.58 & 99.54 & 7.80 \\
Observed runoff & 0.96 & 98.49 & 8.33 \\
\hline
\end{tabular}




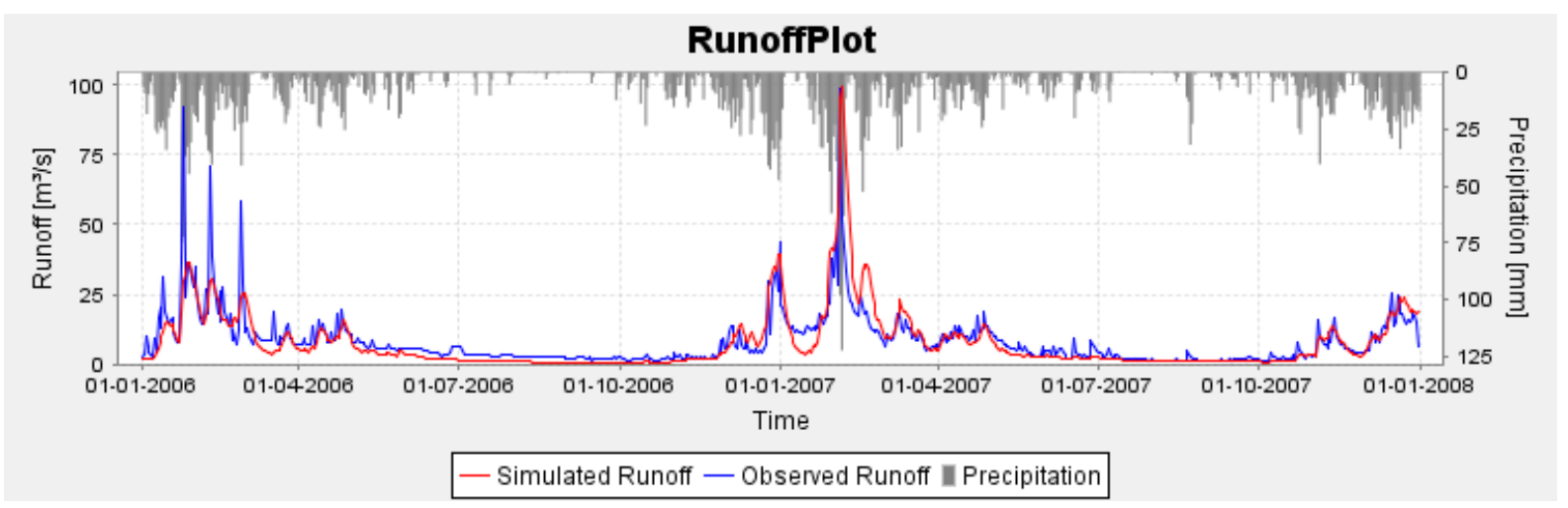

Figure 2. Observed runoff vs. simulated runoff in Katulampa gauging station

Simulated runoff can be separated into four runoff components. This allows distinguishing the origin of runoff. During the flood events, the high runoff is produced by overland flow with $89 \%$ of total runoff. The overland flow is originated from the excess of saturated soil in high precipitation and also from the sealed area. At that day, the precipitation is nine times higher than the daily average precipitation in the wet season.

We found that the flood in Jakarta can be detected earlier in Katulampa gauging station. The 2007 Jakarta flood was caused by the high precipitation. The results show that the hydrological model can be employed to reconstruct the hydrological dynamic during the extreme events (i.e. high precipitation). This model offers the powerful tool to assess the impact of climate and landscape on water movement. Katulampa station where is located in the upper part of Ciliwung is proposed as an early warning system to aware of water flow before entering to the lowlands area (i.e. Jakarta).

\section{ACKNOWLEDGEMENT}

The authors would like to thank Directorate General of Higher Education (Direktorat Jenderal Pendidikan Tinggi - DIKTI), the Republic of Indonesia and German Academic Exchange Service (Deutscher Akademischer Austausch Dienst - DAAD) for providing Indonesian-German Scholarship Program (IGSP). Valuable discussions with Dr. Santhos Nepal are acknowledged.

\section{REFERENCES}

Amien, I., Rejekiningrum, P., Pramudia, A., Susanti, E., 1996. Effects of interannual climate variability and climate change on rice yield in Java, Indonesia. Water, Air, and Soil Pollution 92, 29-39.

Firman, T., 2009. The continuity and change in mega-urbanization in Indonesia: a survey of Jakarta-Bandung Region (JBR) development. Habitat Int 33:327-339. doi:10.1016/j.habitatint.2008.08.005.

Flügel, W.-A., 1995. Delineating Hydrological Units (HRU's) by GIS analysis for regional hydrological modelling using PRMS/MMS in the drainage basin of the River Broel, Germany. Hydrological Processes 9, 423-436.

Förster, H., Sterzel, T., Pape, C.A., Moneo-Lain, M., Niemeyer, I., Boer, R., Kropp, J.P., 2011. Sea-level rise in Indonesia: on adaptation priorities in the agricultural sector. Regional Environmental Change 11, no. 4: 893-904.

Hasanah, Y., Herlina, M., Zaikarina, H., 2013. Flood Prediction using Transfer Function Model of Rainfall and Water Discharge Approach in Katulampa Dam. Procedia Environmental Sciences, 17, 317-326.

Huang, M., Liang, X., 2006. On The Assessment of The Impact of Reducing Parameters and Identification of Parameter Uncertainties for A Hydrologic Model with Applications to Ungauged Basins, Journal of Hydrology 320, 37-61.

IPCC., 2001. Climate change 2001: The scientific basis. Contribution of Working Group I to the Third Assessment Report of the IPCC. Cambridge University Press, Cambridge.

Julian, M.M., Fink, M., Fischer, C., Krause, P., Flügel, W.-A., 2013. Implementation of J2000 Hydrological Model in the Western Part of Java Island, Indonesia. MacroTrend Conference on Applied Science, 20-21 December 2013, Paris, France.

Julian, M.M., Nishio, F., Poerbandono, Ward, P.J., 2011. Simulation of river discharges in major watersheds of northwestern Java from 1901 to 2006, International Journal of Technology 2011 (1), 10-19.

Kralisch, S., Krause, P., 2006. JAMS A Framework for Natural Resource Model Development and Application. In: Proceedings of the International Environmental Software Society (IEMSS), Vermont, USA

Kralisch, S., Krause, P., Fink, M., Fischer, C., Flügel, W.-A., 2007. Component based environmental modelling using the JAMS framework. In: MODSIM 2007 International Congress on Modelling and Simulation. pp. 812-818, peer reviewed.

Krause, P., 2001. Das hydrologische Modellsystem J2000 - Beschreibung und Anwendung in groen Flugebieten, Schriften des Forschungszentrums Julich, Reihe Umwelt/Environment, 29.

Monteith, J.L., 1975. Vegetation and atmosphere, Vol.1 Principles; Academic Press; London.

Oki, K., Noda, K., Yoshida, K., Azechi, I., Maki, M., Homma, K., Hongo, C., Shirakawa, H., 2013. Development of an Environmentally Advanced Basin Model in Asia.

Texier, P., 2008. Floods in Jakarta: when the extreme reveals daily structural constraints and mismanagement. Disaster Prevention and Management, 17(3), 358-372.

Verburg P.H., Veldkamp T.A., Bouma J., 1999. Land use change under conditions of high population pressure: the case of Java. Global Environ Chang 9:303-312. doi:10.1016/S0959-3780(99)00175-2. 